\title{
BRPKM
}

Buletin Riset Psikologi dan Kesehatan Mental

http://e-journal.unair.ac.id/index.php/BRPKM

e-ISSN: 2776-1851

ARTIKEL PENELITIAN

\section{Pengaruh Dukungan Sosial Teman Sebaya terhadap Motivasi Berprestasi Siswa Tunarungu di Sekolah Inklusi}

\author{
Eza Wahyuni Suraida \& Tino Leonardi* \\ Fakultas Psikologi Universitas Airlangga
}

\begin{abstract}
ABSTRAK
Penelitian ini bertujuan untuk menguji pengaruh dukungan sosial teman sebayaterhadap motivasi berprestasi siswa tunarungu di sekolah inklusi SMA sederajat. Metode dalam penelitian ini adalah kuantitatif eksplanatori dengan melakukan survei serta melibatkan 32 koresponden tunarungu, dengan kategori ringan sampai sedang. Alat ukur dukungan sosial yang digunakan peneliti memiliki koefisien reliabilitas cronbach alpha sebesar 0,929. Alat ukur motivasi berprestasi memiliki koefisien reliabilitas cronbach alpha sebesar 0,910. Analisis data menggunakan SPSS 22 for windows. Hasil analisis data menunjukkan bahwa dukungan sosial teman sebaya memiliki pengaruh yang signifikan terhadap motivasi berprestasi. Hal tersebut terlihat dari taraf signifikansi yang kurang dari 0,05, yaitu sebesar 0,000. Dukungan sosial teman sebaya dapat memengaruhi siswa tunarungu di sekolah inklusi SMA sederajat sebesar $85,2 \%(R=0,852)$.
\end{abstract}

Kata kunci: dukungan sosial, motivasi, siswa tunarungu

\begin{abstract}
This study aims to examine the effect of peer social support on achievement motivation of deaf students in inclusive high school equivalents. The method in this study is quantitative explanatory by conducting a survey and involving 32 deaf correspondents, with mild to moderate categories. The measuring tool for social support used by researchers is a measuring tool with a Cronbach alpha reliability coefficient of 0.929. The measuring tool for achievement motivation uses a measuring tool with a Cronbach alpha reliability coefficient of 0.910 . Data analysis using SPSS 22 for windows. The results of data analysis show that peer social support has a significant influence on achievement motivation. This can be seen from the significance level which is less than 0.05 , which is 0.000 . Peer social support can affect deaf students in high school inclusion equivalents by $85.2 \%(\mathrm{R}=0.852)$.
\end{abstract}

Keywords: social support, motivation, deaf students

Buletin Penelitian Psikologi dan Kesehatan Mental (BRPKM), 2021, Vol. 1(2), 1462-1467

*Alamat korespondensi: Fakultas Psikologi Universitas Airlangga, Kampus B Universitas Airlangga Jalan Airlangga 4-6 Surabaya 60286. Surel: tino.leonardi@psikologi.unair.ac.id

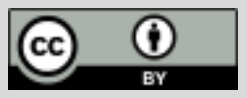

Naskah ini merupakan naskah dengan akses terbuka dibawah ketentuan the Creative Common Attribution License (CC-BY-4.0) (http://creativecommons.org/licenses/by/4.0), sehingga penggunaan, distribusi, reproduksi dalam media apapun atas artikel ini tidak dibatasi, selama sumber aslinya disitir dengan baik. 


\section{PENDAHULUAN}

Mendapatkan pendidikan yang baik merupakan hak setiap individu. Hal ini telah dituangkan dalam dalam pasal 31 UUD 1945 “Tiap-tiap warga negara berhak mendapatkan pengajaran”. Sehingga dapat dikatakan bahwa setiap warga negara berhak mendapatkan pendidikan yang baik termasuk individu yang memiliki kebutuhan khusus, Dikatakan dalam Undang-Undang nomor 20 Tahun 2003 pasal 5 ayat 2 "Warga negara yang memiliki kelainan fisik, emosional, mental, intelektual, dan atau sosial berhak memperoleh pendidikan khusus".

Siswa dengan tunarungu merupakan salah satu dari siswa berkebutuhan khusus yang berhak mendapatkan pendidikan khusus. Berdasarkan data yang dipublikasikan oleh Pusat Data dan Informasi Kementrian Kesehatan RI, persentase penyandang disabilitas rungu di Indonesia mencapai 7,03\% (Harpini, 2019). Sedangkan pada data Badan Pusat Statistik tahun 2010, Kota Surabaya merupakan wilayah yang memiliki penduduk dengan tunarungu tertinggi di Provinsi Jawa Timur yaitu sebanyak 7,39\% dari 7,3 juta jiwa. Menurut data tersebut juga ditemukan bahwa sekitar 19,7\% pengidap tunarungu berada di masa remaja, yaitu usia 10-19 tahun (Hasan \& Handayani, 2014).

Anak berkebutuhan khusus memiliki motivasi berprestasi yang mengalami fluktuasi tergantung faktor yang memengaruhinya. Dengan kebutuhan-kebutuhan yang terpenuhi maka anak berkebutuhan khusus akan memunculkan motivasi berprestasi.

Motivasi berprestasi merupakan hasrat untuk menyelesaikan tugas, demi mencapai suatu standardan sebuah usaha untuk mencapai kesuksesan McCelland (1987 dalam Santrock, 2003). Adapun faktorfaktor yang memengaruhi motivasi berprestasi menurut Morgan \& King (1990 dalam Nasution, 2017) ialah perilaku dan karakteristik model yang ditiru melalui observational learning, pola asuh, penekanan kemandirian, harapan orang tua, dan lingkungan. Oleh karena itu pengaruh lingkungan menjadi salah satu faktor yang dapat mempengaruhi motivasi berprestasi. Menurut Robinson (1995 dalam Papalia, Old, \& Feldmann, 2008) keberadaan teman sebaya sangat penting bagi kehidupan remaja untuk memperoleh dukungan yang baik dari sebayanya. Dukungan yang diperoleh dari teman sebaya mampu memberikan rasa nyaman pada individu secara fisik maupun psikologis (Baron \& Byrne, 2003). Teman sebaya dapat mendukung pendidikan inklusif baik dalam hal meningkatkan komunikasi, penerimaan keragaman, keterampilan sosial, termasuk penyesuaian diri pada siswa tunarungu (Bond \& Castagnera, 2006). Dengan adanya dukungan tersebut akan memberikan efek yang positif dan dapat mengurangi gangguan psikologis pada seseorang.

Menurut Rubenstein (1989 dalam Santrock, 2003) akibat dari tidak adanya dukungan yang diterima oleh remaja dari teman sebaya dapat menimbulkan tidak adanya semangat serta tidak mampu berprestasi. Eccles, dkk. (1993 dalam Santrock, 2008) menjelaskan bahwa perbandingan sosial, belajar bersama, kompetensi dan motivasi sosial, dan pengaruh kelompok pertemanan dapat memengaruhi motivasi.

Dengan demikian, dukungan sosial teman sebaya menjadi salah satu faktor penting yang dapat membuat para siswa tunarungu termotivasi dalam belajar. Sehingga, peneliti tertarik untuk melihat apakah dukungan sosial teman sebaya memiliki pengaruh pada motivasi berprestasi siswa dengan tunarungu di sekolah inklusi SMA sederajat. 


\section{METODE}

\section{Desain Penelitian}

Pada penelitian ini, penulis menggunakan tipe penelitian kuantitatif. Data dari penelitian kuantitatif memiliki ciri-ciri berupa data kuantifikasi dan perekapan. Pada penelitian kuantitatif terdapat empat model dalam pengolahan data, yakni uji korelasi, regresi, pengaruh, dan komparatif. Penelitian ini mencari hasil pengaruh dukungan sosial teman sebaya terhadap motivasi berprestasi siswa tunarungu di sekolah inklusi SMA sederajat, penulis menggunakan uji regresi untuk mencari hasil pengaruh kedua variabel tersebut. Populasi dalam penelitian ini adalah siswa tuna rungu dengan kategoris ringan sampai sedang yang bersekolah di sekolah inklusi.

\section{Partisipan}

Partisipan dalam penelitian ini adalah siswa SMA sederajat dengan tunarungu kategori ringan-sedang. Partisipan dalam penelitian ini dipilih menggunakan teknik purposive sampling. Menurut Sugiyono (2016) purposive sampling adalah teknik dimana sampel dipilih sesuai dengan karakteristik yang sesuai. Berikut merupakan karakteristik sampel dalam penelitian ini: a. siswa tunarungu dengan kategori ringan-sedang; b. siswa sekolah inklusi.

Peneliti menyebarkan kuesioner daring melalui google form yang telah diisi oleh 32 siswa tunarungu (59,4\% perempuan; 40,6\% laki-laki) dan menjadi partisipan dalam penelitian ini. Jika dilihat dari karakteristik kategori tunarungu maka siswa dengan tunarungu ringan sama dengan siswa tunarungu sedang, yaitu masing-masing 50 persen atau 16 partisipan disetiap kategorinya.

\section{Pengukuran}

Instrumen penelitian untuk mengambil data tentang motivasi berprestasi menggunakan kuesioner "Motivasi Berprestasi" yang disusun oleh Prihandrijani (2016). Instrumen penelitian ini menggunakan skala likert dengan empat pilihan jawaban (Sangat Suka, Suka,Tidak Suka, dan Sangat Tidak Suka) dengan 23 aitem pernyataan. Kemudian untuk reliabilitas yang dimiliki adalah sebesar .91. Sedangkan instrumen penelitian untuk mengambil data tentang dukungan sosial teman sebaya akan menggunakan kuesioner yang disusun oleh Hasan (2014). Instrumen penelitian ini menggunakan skala likert dengan empat pilihan jawaban (Sangat Suka, Suka, Tidak Suka, dan Sangat Tidak Suka) dengan 22 aitem pernyataan. Kemudian untuk reliabilitas yang dimiliki adalah sebesar .929.

\section{Analisis data}

Uji asumsi yang dilakukan penulis ialah uji normalitas, linearitas, dan homoskedastisitas. Uji normalitas dalam penelitian ini 200 bermakna bahwa penelitian ini memenuhi syarat normalitas, uji linearitas dalam penelitian ini 167 bermakna penelitian ini linear, dan sebaran data merata tidak membentuk pola tertentu sehingga memenuhi kaidah homoskedastisitas. Uji statistik yang digunakan oleh penulis menggunakan uji regresi sederhana, menggunakan bantuan SPSS 25.0 for windows untuk menguji pengaruh kedua variabel yang telah disebutkan sebelumnya pada siswa tunarungu di sekolah inklusi SMA sederajat.

\section{HASIL PENELITIAN}

Berdasarkan hasil uji korelasi diketahui bahwa dukungan sosial teman sebayaberkorelasi positif dan cenderung kuat $(r(32)=-0,852$; sig. $<0.005)$ dengan motivasi berprestasi taraf signifikansi 0,000 . setelah dilakukan analisis regresi linier sederhana, hal tersebutmampu menjelaskan data $(\mathrm{R}=0.852 ; p<0,005$;

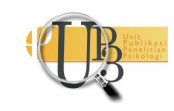


$R^{2}=0.727$ ) dan varians prediktor dapat menjelaskan 72.7 persen dari varians variabel dependen. Dukungan sosial teman sebaya berkorelasi positif dan kuat dalam menjelaskan motivasi berprestasi dengan taraf signifikansi 0.000. Disimpulkan bahwa hasil dari penelitian ini, dukungan sosial teman sebaya memiliki pengaruh yang kuat dan taraf signifikansi yang baik terhadap motivasi berprestasi siswa tunarungu sekolah inklusi SMA sederajat.

\section{DISKUSI}

Hasil dari penelitian ini menunjukkan adanya pengaruh yang signifikan antara variabel X terhadap variabelY pada penelitian ini, sehingga $\mathrm{H}_{\mathrm{a}}$ pada penelitian ini diterima. Hasil analisis regresi linear sederhana menunjukkan hasil dimana variabel $\mathrm{X}$ pada penelitian iniberkorelasi positif dengan derajat kuat terhadap variabel Y, sehingga ketika variabel Xterkait motivasi berprestasitinggi maka variabel Y juga akan meningkat. Selanjutnya taraf signifikansi pada penelitian ini menunjukkan bahwa variabel Xberpengaruh signifikan terhadap terbentuknya atau meningkatnya motivasi berprestasi siswa tunarungu.

Hasil dalam penelitian ini didukung oleh penelitian yang sudah dilakukan peneliti lain, yakni dukungan sosial teman sebaya dapat memengaruhi motivasi berprestasi siswa tunarungu. Seperti dalam penelitian yang menyebutkan bahwa keberhasilan siswa dalam pendidikan dipengaruhi oleh motivasi berprestasi, variabel yang diujikan juga dukungan teman sebaya dan motivasi berprestasi yang diujikan pada 227 subjek laki-laki dan 89 subjek perempuan. Hasilnya adalah variabel dukungan teman sebaya memiliki hubungan yang positif dan signifikan terhadap variabel motivasi berprestasi dengan koefisien korelasi sebesar $(r(316)=-0,397 ; p<0.001)$. Dapat diartikan dari penelitian tersebut bahwa jika nilai dukungan teman sebaya positif, maka motivasi berprestasi juga ikut tinggi(Ulfah \& Ariati, 2018).

Pada penelitian yang dilakukan oleh Hilmi (2014) yang mengambil topik sama yakni dukungan sosial teman sebaya dengan motivasi berprestasi, menunjukkan hasil 71\% kategori tinggi, 27\% sedang dan $2 \%$ kategori rendah. Sedangkan variabel motivasi berprestasi $72 \%$ tinggi, $26 \%$ sedang, dan $2 \%$ kategori rendah. Dapat disimpulkan kedua variabel tersebut berpengaruh positif dengan nilai 0,158.

Dari pembahasan diatas dapat peneliti simpulkan bahwa hasil penelitian sudah dapat menjawab rumusan masalah penelitian, yakni terdapat pengaruh yang kuat antara dukungan sosial teman sebaya dengan motivasi berprestasi siswa tunarungu di sekolah inklusi SMA sederajat.

Penelitian yang membahas tentang topik yang serupa diambil oleh penulis pada siswa tunarungu di sekolah inklusi belum banyak dan menjadi salah satu keterbatasan pada penelitian ini. Salah satu penelitian yang dilakukan oleh Hasan dan Handayani (2014), mengemukakan hasil penelitiannya yakni terkait dukungan sosial pada penyesuaian diri siswa tunarungu di sekolah inklusi, kedua peneliti tersebut menggunakan uji korelasi pada variabel dan menjelaskan hubungan yang dimiliki bernilai positif dan signifikan.

\section{SIMPULAN}

Penelitian ini berfokus pada peran dukungan sosial teman sebayaterhadap motivasi berprestasisiswa tunarungu di sekolah inklusi SMA sederajat. Menurut hasil analisis ini menunjukkan bahwa dukungan sosial teman sebayamemiliki pengaruh signifikan terhadap motivasi berprestasisiswa tunarungu di 
sekolah inklusi SMA sederajat. Dengan hasilkolerasi positif dengan derajat kuat, ketika variabel Xtinggi makavariabel Y padasiswa tunarungu juga ikut meningkat.

\section{UCAPAN TERIMAKASIH}

Peneliti mengucapkan banyak terimakasih kepada kedua orangtua, adik, pasangan, sahabat, teman, serta pihak-pihak yang lain yang telah membantu dalam proses pengerjaannya.

\section{DEKLARASI POTENSI TERJADINYA KONFLIK KEPENTINGAN}

Eza Wahyuni Suraida dan Tino Leonardi tidak bekerja, menjadi konsultan, memiliki saham, atau menerima dana dari perusahaan atau organisasi manapun yang mungkin akan mengambil untung dari diterbitkannya naskah ini.

\section{PUSTAKA ACUAN}

Baron, R. A., \& Byrne, D. (2003). Psikologi Sosial. Jakarta: Erlangga.

Bond, R., \& Castagnera, E. (2006). Peer supports and inclusive education: An underutilized resource. Theory into Practice, 45(3), 224-229. https://doi.org/10.1207/s15430421tip4503_4

Harpini, A. (2019). Infodatin Disabilitas Rungu (p. 12). Retrieved from https://pusdatin.kemkes.go.id/resources/download/pusdatin/infodatin/infodatin-tunarungu2019.pdf

Hasan, S. A., \& Handayani, M. M. (2014). Hubungan antara Dukungan Sosial Teman Sebaya dengan Penyesuaian Diri Siswa Tunarungu di Sekolah Inklusi. Psikologi Perkembangan Dan Pendidikan, $3(2), 128-135$.

Hilmi, M. S. (2014). Pengaruh Dukungan Sosial Teman Sebaya terhadap Motivasi Berprestasi Siswa SMKN II Malang. [Skripsi, Universitas Negeri Maulana Malik Ibrahim]. http://etheses.uinmalang.ac.id/904/

Nasution, S. I. (2017). Analisis faktor-faktor yang berpengaruh terhadap motivasi berprestasi mahasiswa prodi manajemen pendidikan islam fakultas tarbiyah dan keguruan uin raden intan lampung. Jurnal Kependidikan Islam, 7(2), 38-54.

Papalia, D. E., Old, S. W., \& Feldmann, R. D. (2008). Human Development (terjemahan A. K. Anwar). Jakarta: Prenada Media Group.

Prihandrijani, E. (2016). Pengaruh Motivasi Berprestasi dan Dukungan Sosial Terhadap Flow Akademik Pada Siswa Sma " $X$ " Di Surabaya. [Tesis, Universitas Airlangga]. https://repository.unair.ac.id/46847/

Santrock, J. W. (2003). Adolescence. Jakarta: PT. Erlangga. 
Santrock, J. W. (2008). Perkembangan Anak. Jilid 1 Edisi Kesebelas. Jakarta: PT. Erlangga.

Sugiyono. (2016). Metode Penelitian Kuantitatif, Kualitatif dan R\&D. Bandung: Alfabet.

Ulfah, A. N., \& Ariati, J. (2018). Hubungan Dukungan Teman Sebaya Dengan Motivasi Berprestasi Pada Santri Pesantren Islam Al-Irsyad, Kecamatan Tengaran, Kabupaten Semarang. JurnalEmpati, 6(4), 297-301. 